\title{
Larval Hook Length Measurement for Differentiating G1 and G6 Genotypes of Echinococcus granulosus Sensu Lato
}

Larval Gengellerinin Uzunluğunun Ölçülmesi ile Echinococcus granulosus Sensu Lato

G1 ve G6 Genotiplerinin Ayrılması

\author{
Majid Fasihi Harandi ${ }^{1}$, Elham Hajialilo' ${ }^{1}$ Mostafa Shokouhi \\ 'Department of Parasitology, Faculty of Medicine, Kerman University of Medical Sciences, Kerman, Iran \\ ${ }^{2}$ Physiology Research Center, Faculty of Medicine, Kerman University of Medical Sciences, Kerman, Iran
}

\section{ABSTRACT}

Objective: Echinococcus granulosus is a globally important cestode parasite causing remarkable medical and economical losses in the world. Ten genotypes (G1-G10) have been identified within this complex species. Protoscoleces rostellar hook characters e.g. total large and small hook lengths may be useful to differentiate genotypes. This study investigates the value of rostellar hook morphometry on genetically identified isolates of E. granulosus using mitochondrial cox1 and nad1 sequencing.

Methods: In total, 24 hydatid cyst samples of livestock and human origin were collected. The isolates were then sequenced for the mitochondrial cox1 and nad1 genes and total large and small rostellar hook lengths of protoscoleces were measured.

Results: Total large and small hook lengths could differentiate between G1 and G6 genotypes; however, G1 and G3 were not distinguishable by hook morphometry. Only large hook length was significantly different between the $\mathrm{G} 3$ and $\mathrm{G} 6$ isolates.

Conclusion: The G6 genotype is readily distinguishable from G1 by using both small and large hook lengths; however, only total large hook length was significantly different between the G3 and G6 genotypes. (Turkiye Parazitol Derg 2012; 36: 215-8)

Key Words: Hook morphometry, hydatid disease, Genotype, cox1, nad1

Received: 18.03.2012

Accepted: 07.09.2012

\section{ÖZET}

Amaç: Echinococcus granulosus dünya çapında görülen, büyük ekonomik kayıplara neden olan ve halk sağlığı bakımından tıbbi önemi olan bir parazittir. Bu parazitin suş karakterizasyon yapılmış ve 10 tane genotipi (G1-G10) olduğu tespit edilmiştir. Protoscolexlerin rostellum etrafındaki büyük ve küçük çengellerin uzunluğu Echinococcus granulosus genotiplerini ayırt etmekte yararlı olabilir. Bu çalışma rostellum çengellerinin uzunluğunun ölçülmesinin değerini mitokondriyal cox1 ve nad1 sıralama kullanarak Echinococcus granulosus suşlarının ayrılmasını incelemektedir.

Yöntemler: Hayvan ve insan kaynaklı 24 hidatik kist örnekleri toplanıp ve daha sonra mitokondriyal cox1 ve nad1 genler sekanslandı. Protoskolekslerin büyük ve küçük rostellar çengellerinin uzunlukları ölçüldü.

Bulgular: Sonuçlar bunu gösteriyor ki büyük ve küçük çengellerinin uzunluğu G1 ve G6 genotiplerini arasında ayrım yapabilir, halbuki G1 ve G3 genotiplerini birbirinden ayıramamaktadır. Büyük çengellerin uzunluğu G3 ve G6 genotipleri arasında anlamlı olarak fark vardı.

Sonuç: G1 ve G6 genotipleri büyük ve küçük çengellerin uzunluğunu kullanarak birbirinden ayrıldığı; bununla birlikte G3 ve G6 genotiplerinin sadece büyük çengellerinin uzunluğunun birbirinden önemli derecede farklı olduğu belirlendi. (Turkiye Parazitol Derg 2012; 36: 215-8)

Anahtar Sözcükler: Çengellerinin morfometri, hidatik kist, genotip, cox1, nad1

Geliş Tarihi: 18.03.2012

Kabul Tarihi: 07.09.2012

Address for Correspondence / Yazışma Adresi: Dr. Majid Fasihi Harandi, Department of Parasitology, Faculty of Medicine, Kerman University of Medical Sciences, Kerman, Iran Phone: +98 3413236374 Fax: +98 3413221676 E-mail: majid.fasihi@gmail.com doi:10.5152/tpd.2012.52 


\section{INTRODUCTION}

Echinococcus granulosus, the aetiological agent of cystic echinococcosis (CE), is the smallest tapeworm of the family Taeniidae. CE is one of the most important parasitic zoonoses worldwide. The parasite is mainly transmitted among dogs as the definitive hosts and livestock animals as the intermediate host (1).

Several genetic studies have demonstrated the high intra-specific variability within this species that is collectively known as Echinococcus granulosus sensu lato. E. granulosus s.l. is comprised of a complex of ten genotypes (G1-G10) of which four genotypes are considered distinct species, i.e. E. granulosus sensu stricto (G1-G3), E. equinus (G4), E. ortleppi (G5), and E. canadensis (G6-G10). Different genotypes of the parasite have distinct morphological, epidemiological and transmission dynamics characterisations (2). It is believed that these characterisations have important implications in terms of epidemiology and the control of hydatid disease. However, solid evidence of these implications is still needed (3). Clearly, more large-scale molecular epidemiological studies in different geographical areas are necessary to elucidate the nature and significance of variability in E. granulosus s.l. and its implications for public health (2).

Regarding the relatively high cost of DNA sequencing on a large number of E. granulosus isolates, morphometric data could be potentially useful for screening large numbers of isolates for sequencing. Large-scale sequence-based studies are expensive and less accessible in many research laboratories in endemic areas, which constitutes a major obstacle for conducting high quality research projects. Larval rostellar hook characters, e.g. total large and small hook length, are potentially good tools for screening large numbers of $E$. granulosus isolates of different genotypes $(4,5)$. However, the value of morphometry for distinguishing genotypes of E. granulosus s.l. compared to DNA-based methods is not clearly shown. Very few studies have investigated the accuracy of hook morphometry on known genetically characterised isolates using DNA sequencing. The aim of this study is to determine the value of rostellar hook morphometry in the identification of different genotypes of $E$. granulosus s.l.

\section{METHODS}

Twenty-four hydatid cyst samples were collected from sheep (14), goat (2), cattle (1), camels (6) and humans (1) originating from locations within Kerman Province, south-eastern Iran. All animals were slaughtered in local abattoirs in Kerman and Rafsanjan cities. The human sample was from a female patient who was operated on at the Afzalipour Medical Centre in Kerman. Each individual cyst was considered an E. granulosus isolate. Protoscoleces were aspirated from cysts and washed three times with normal saline. After extracting DNA using the High Pure PCR Template Preparation Kit (Roche, Mannheim, Germany), all of the isolates were genotyped by sequencing of two mitochondrial genes, cox1 and nad1, using the primers JB3 and JB4.5 for cox1 and JB11 and JB12 for nad1 (6, 7). E. granulosus sequence data were deposited in the NCBI GenBank database (Figure 1).

For the morphometric study, protoscoleces were mounted in lactophenol on a glass slide and sufficient pressure was applied using a cover slip to cause the hooks to lie flat. Measurements were made of total hook length on two large and two small hooks per rostellum from each of five protoscoleces for each isolate using 100X magnification of a calibrated microscope (Figure 2, 3). One person (E.H.) carried out all of the measurements $(8,9)$.

Results of large and small hook data were analysed using SPSS ver. 15. Morphometric differences between the G1, G3 and G6 genotypes were analysed by a two-dimensional scatter plot and

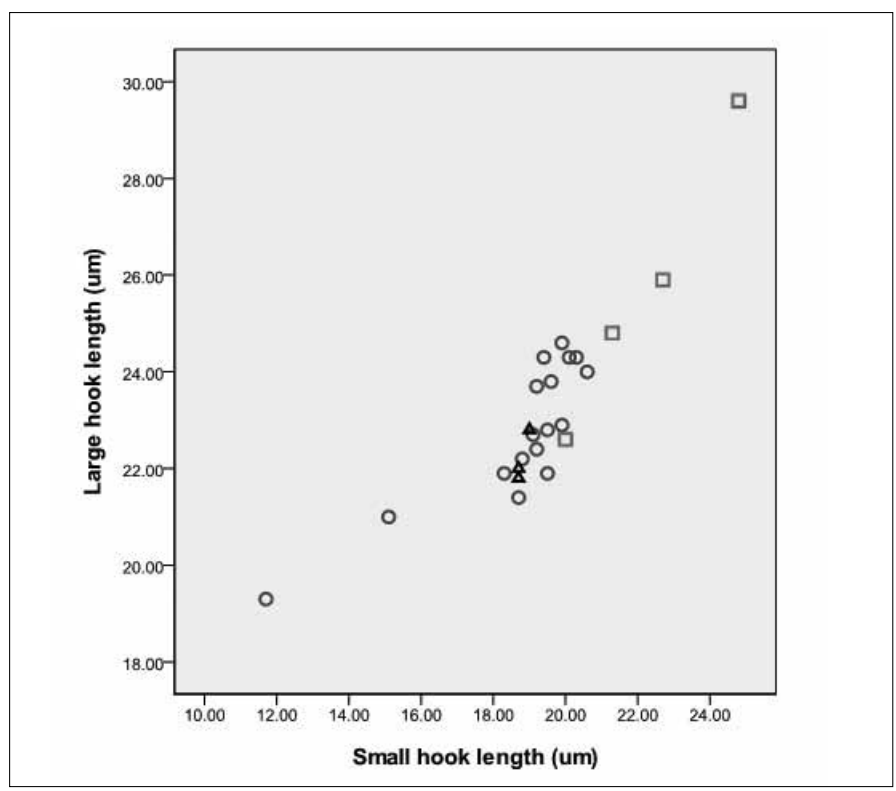

Figure 1. Scatter plot of the total large and small hook lengths according to genotypes for the 24 isolates of $E$. granulosus measured in this study. (O) G1; $(\Delta) \mathrm{G} 3$; ( $\square)$ G6. Sequence data of all of the isolates was submitted to NCBI GenBank with the following accession numbers: cox1: HM563002, HM563011-14, HM563016-20, and nad1: HM563023, HM563025-30, HM56303233, HM563035-37

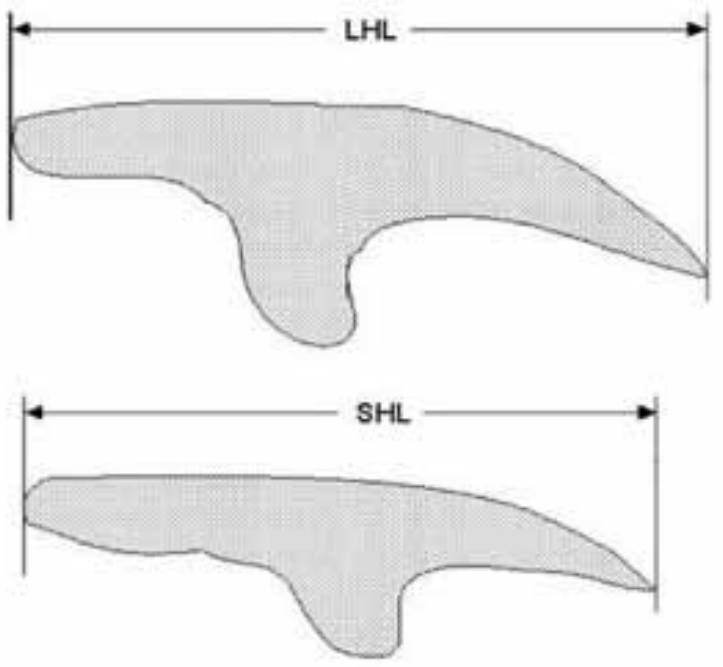

Figure 2. Diagram of rostellar hook measurements used in this study. Large Hook Length (LHL), Small Hook Length (SHL) 
Table 1. Statistical analysis of mean differences of larval rostellar hook lengths in different genotypes of $E$. granulosus s.l. isolates

\begin{tabular}{|c|c|c|c|c|c|c|}
\hline Dependent variable & Genotype (No.) & Mean (SD) & $p$ value* & \multicolumn{2}{|c|}{ Group } & p value ${ }^{\star \star}$ \\
\hline \multirow{6}{*}{ Small Hook Length $(\mu \mathrm{m})$} & \multirow[t]{2}{*}{ G1 (17) } & \multirow[t]{2}{*}{$18.75(2.18)$} & \multirow{6}{*}{0.008} & \multirow{2}{*}{ G1 } & G6 & 0.02 \\
\hline & & & & & G3 & 0.99 \\
\hline & \multirow[t]{2}{*}{ G6 (4) } & \multirow[t]{2}{*}{$22.20(2.05)$} & & \multirow{2}{*}{ G6 } & G1 & 0.02 \\
\hline & & & & & G3 & 0.12 \\
\hline & \multirow[t]{2}{*}{ G3 (3) } & \multirow[t]{2}{*}{$18.80(0.17)$} & & \multirow{2}{*}{ G3 } & G1 & 0.99 \\
\hline & & & & & G6 & 0.12 \\
\hline \multirow{6}{*}{ Large Hook Length $(\mu \mathrm{m})$} & \multirow[t]{2}{*}{ G1 (17) } & \multirow[t]{2}{*}{$22.79(1.43)$} & \multirow{6}{*}{0.055} & \multirow{2}{*}{ G1 } & G6 & 0.02 \\
\hline & & & & & G3 & 0.85 \\
\hline & \multirow[t]{2}{*}{ G6 (4) } & \multirow[t]{2}{*}{$25.72(2.92)$} & & \multirow{2}{*}{ G6 } & G1 & 0.02 \\
\hline & & & & & G3 & 0.04 \\
\hline & \multirow[t]{2}{*}{ G3 (3) } & \multirow[t]{2}{*}{$22.20(0.53)$} & & \multirow{2}{*}{ G3 } & G1 & 0.85 \\
\hline & & & & & G6 & 0.04 \\
\hline
\end{tabular}

Kruskal-Wallis test followed by the Bonferroni multiple comparison test to determine where differences occur among group means. A statistical significance of $p<0.05$ was considered significant.

\section{RESULTS}

Hook length data of the present study showed that G6 isolates have significantly larger hook lengths than G1 isolates (Figure 3, Table 1); therefore, both genotypes could be differentiated using small and large hook length measurements. However, there was no statistically significant difference in hook dimensions between the G1 and G3 genotypes (Table 1). In hook morphometry, only the large hook length significantly differentiated the G3 and G6 isolates $(p<0.05)$. According to our data, the sensitivity and specificity of total hook length for genotype identification was $100 \%$ and $75 \%$, respectively.

\section{DISCUSSION}

The emergence of DNA-based molecular techniques provided a sensitive and reliable tool to understand the nature of variation within and between species and strains of helminth parasites (10). As a consequence, morphological tools have been undermined in recent years due to the loss of expertise and interest in traditional morphological studies (11). However, it is believed that molecular and morphological characters are complementary in epidemiological studies on cestode zoonoses, like cystic echinococcosis. Morphological and biological studies during the 1970s and 1980s had made major progress towards understanding intra-specific variation in $E$. granulosus leading to the identification of different strains of the parasite (12-15). Later, molecular DNA-based studies confirmed the presence of ten genotypes within this complex species (G1-G10). However, the taxonomic status of E. granulosus is not clear and large-scale molecular epidemiological studies in different endemic areas across the globe are obviously needed. Regarding high cost and availability considerations of this kind of studies in endemic areas, protoscoleces hook morphometry could be used as an

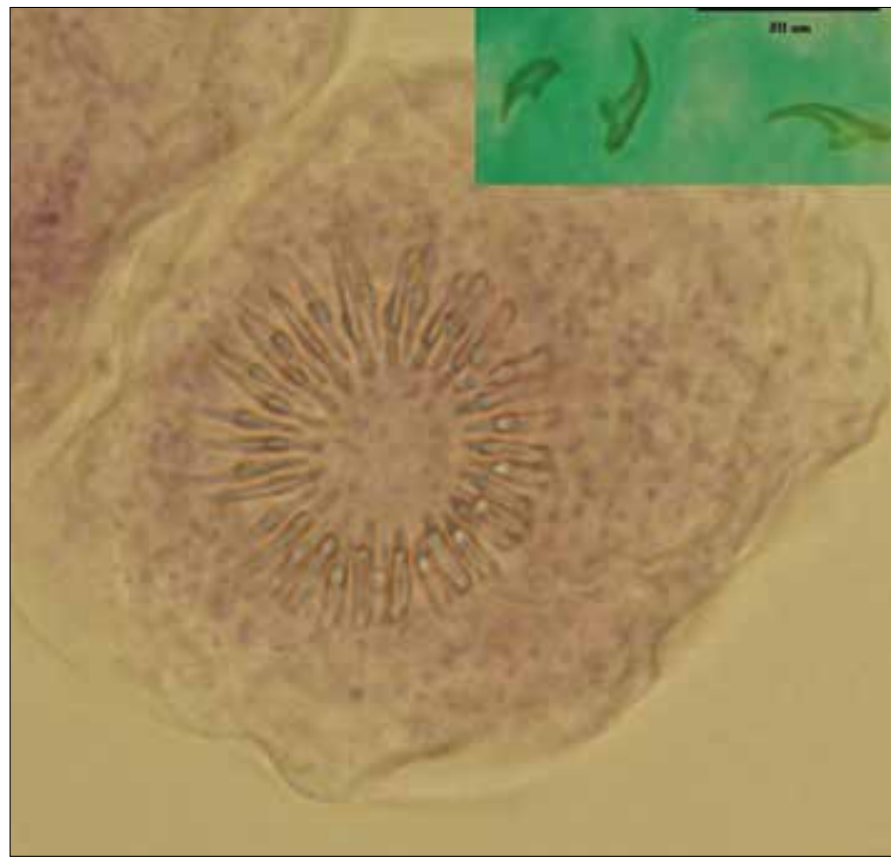

Figure 3. Rostellar hooks of a G6 camel isolate of Echinococcus granulosus protoscolex with one small and two large hooks shown in the inlet box. Bar $=50 \mu \mathrm{m}$

alternative for strain identification of E. granulosus when screening large numbers of isolates. However, the value of rostellar hook characters for genotype identification of the parasite is not clearly shown (16). Among the different rostellar hook characters, the total lengths of small and large hooks were shown to be the most suitable characters for strain identification (4).

The results of the present study indicate that the $\mathrm{G} 6$ genotype is readily distinguishable from $\mathrm{G} 1$ by using both small and large hook lengths; however, only total large hook length was significantly different between G3 and G6 genotypes. Turceková et al. (17) showed that the shape and size of hooks were suitable for discriminating the $\mathrm{G} 1$ and $\mathrm{G} 7$ genotypes using nad1 sequence 
data as a reference. A study on Mexican pig isolates using PCRRFLP and larval hook measurements showed that pig (G7), camel (G6) and horse (G4) isolates have significantly larger hooks than sheep (G1) strain isolates (18). The morphometry of rostellar hooks was investigated among human and livestock samples from Iran and the results showed that sheep and camel isolates could be differentiated by hook morphometry, although no molecular data was provided in the study for strain identification (5). Another study on ITS1 region, using PCR-RFLP, showed that sheep and camel strains are morphologically distinguishable by the measurements of the total and blade length of rostellar hooks of protoscoleces. This study showed that all human isolates of the G1 genotype had mean large hook length less than $25 \mu \mathrm{m}$, whereas all of the $\mathrm{G} 6$ isolates had hooks larger than 25 $\mu \mathrm{m}$ (8). In the present study, one $\mathrm{G} 6$ isolate of camel origin, confirmed by DNA sequencing, had a large hook length less than 25 $\mu \mathrm{m}$ in total, indicating that morphometry alone could not be relied on as the sole criterion for genotype identification; however, our human isolate was identified as G6 using both DNAsequence and rostellar small/large hook measurements.

This study failed to differentiate between the G1 and G3 isolates, indicating remarkable phenotypic similarities between the two genotypes. This confirms recent categorisation of the $\mathrm{G} 1$ and G3 genotypes along with G2 (G1-G3 complex) as E. granulosus sensu stricto $(19,20)$. Similarly, morphometric analysis of larval rostellar hooks of E. granulosus from Tasmanian (G2) and Australian (G1) host origin showed that these two strains are indistinguishable by hook morphology (9).

Several studies have shown that at least a fraction of hook morphological variation is attributed to host-induced effects $(4,9$, 21); however, this has not been analysed in the present study, because of the small number of isolates in each host category. Extensive studies on a larger number of isolates from different intermediate hosts using morphological and molecular tools are recommended.

\section{CONCLUSION}

We established the value of rostellar hook morphometry for differentiating genotypes of E. granulosus s.I. in Iran. The G6 genotype is readily distinguishable from $\mathrm{G} 1$ by using both small and large hook lengths; however, only total large hook length was significantly different between the $\mathrm{G} 3$ and $\mathrm{G} 6$ genotypes. Hook morphometry could not differentiate between the $\mathrm{G} 1$ and $\mathrm{G} 3$ isolates, indicating remarkable phenotypic similarities between the two genotypes.

\section{Acknowledgements}

The authors thank Mr H.Kamyabi and Mr J Beigzadeh for their assistance in collecting samples from abattoirs. The authors appreciate Prof. K. H. Tappeh for his kind help in editing the Turkish version of the manuscript. This work was an MSc. thesis of E.H. and was financially supported by the Vice-Chancellor for Research, Kerman University of Medical Sciences, grant No. 88-43.

\section{Conflict of Interest}

No conflict of interest was declared by the authors.

\section{REFERENCES}

1. Eckert J, Deplazes P. Biological, epidemiological, and clinical aspects of Echinococcosis, a zoonosis of increasing concern. Clin Microbiol Rev 2004; 17: 107-35. [CrossRef]

2. Thompson RCA. The taxonomy, phylogeny and transmission of Echinococcus. Exp Parasitol 2008; 119: 439-46. [CrossRef]

3. Craig PS, McManus DP, Lightowlers MW, Chabalgoity JA, Garcia $\mathrm{HH}$, Gavidia CM, et al. Prevention and control of cystic echinococcosis. Lancet Infect Dis 2007; 7: 385-94. [CrossRef]

4. Gordo FP, Bandera CC. Differentiation of Spanish strains of Echinococcus granulosus using larval rostellar hook morphometry. Int J Parasitol 1997; 27: 41-9. [CrossRef]

5. Ahmadi NA. Using morphometry of the larval rostellar hooks to distinguish Iranian strains of Echinococcus granulosus. Ann Trop Med Parasitol 2004; 98: 211-20. [CrossRef]

6. Bowles J, Blair D, McManus DP. Genetic variants within the genus Echinococcus identified by mitochondrial DNA sequencing. Mol Biochem Parasitol 1992; 54: 165-73. [CrossRef]

7. Bowles J, McManus DP. NADH dehydrogenase 1 gene sequences compared for species and strains of the genus Echinococcus. Int $J$ Parasitol 1993; 23: 969-72. [CrossRef]

8. Harandi MF, Hobbs RP, Adams PJ, Mobedi I, Morgan-Ryan UM, Thompson RCA. Molecular and morphological characterization of Echinococcus granulosus of human and animal origin in Iran. Parasitology 2002; 125: 367-73.

9. Hobbs RP, Lymbery AJ, Thompson RCA. Rostellar hook morphology of Echinococcus granulosus (Batsch, 1786) from natural and experimental Australian hosts, and its implications for strain recognition. Parasitology 1990; 101: 273-81. [CrossRef]

10. Gasser RB. Molecular tools, advances, opportunities and prospects. Vet Parasitol 2006; 136: 69-89. [CrossRef]

11. Poulin R, Leung TL. Taxonomic resolution in parasite community studies: are things getting worse? Parasitology 2010; 137: 1967-73. [CrossRef]

12. Eckert J, Thompson RCA, Michael SA, Kumaratilake LM, el-Sawah HM. Echinococcus granulosus of camel origin: development in dogs and parasite morphology. Parasitol Res 1989; 75: 536-44. [CrossRef]

13. Kumaratilake LM, Thompson RC, Eckert J. Echinococcus granulosus of equine origin from different countries possess uniform morphological characteristics. Int J Parasitol 1986; 16: 529-40. [CrossRef]

14. Thompson RC, Kumaratilake LM, Eckert J. Observations on Echinococcus granulosus of cattle origin in Switzerland. Int J Parasitol 1984; 14: 283-91. [CrossRef]

15. Smyth J. Strain differences in Echinococcus granulosus, with special reference to the status of equine hydatidosis in the United Kingdom. Trans R Soc Trop Med Hyg 1977; 71: 93-100. [CrossRef]

16. Yildiz K, Gurcan IS. The detection of Echinococcus granulosus strains using larval rostellar hook morphometry. Turkiye Parazitol Derg 2009; 33: 199-202.

17. Turceková L, Snábel V, D’Amelio S, Busi M, DubinskýP. Morphological and genetic characterization of Echinococcus granulosus in the Slovak Republic. Acta Trop 2003; 85: 223-9. [CrossRef]

18. Cruz-Reyes A, Constantine CC, Boxell AC, Hobbs RP, Thompson $\mathrm{RC}$. Echinococcus granulosus from Mexican pigs is the same strain as that in Polish pigs. J Helminthol 2007; 81: 287-92. [CrossRef]

19. Nakao M, McManus DP, Schantz PM, Craig PS, Ito A. A molecular phylogeny of the genus Echinococcus inferred from complete mitochondrial genomes. Parasitology 2007; 134: 713-22. [CrossRef]

20. Saarma U, Jõgisalu I, Moks E, Varcasia A, Lavikainen A, Oksanen A, et al. A novel phylogeny for the genus Echinococcus, based on nuclear data, challenges relationships based on mitochondrial evidence. Parasitology 2009; 136: 317-28. [CrossRef]

21. Lymbery AJ. Combining data from morphological traits and genetic markers to determine transmission cycles in the tapeworm, Echinococcus granulosus. Parasitology 1998; 117: 185-92.[CrossRef] 